\title{
Experimental Organism Histiocytic Lymphoma Neoplasm
}

National Cancer Institute

\section{Source}

National Cancer Institute. Experimental Organism Histiocytic Lymphoma Neoplasm. NCI

Thesaurus. Code C114110.

A malignant neoplasm of large lymphocytes, which resemble histiocytes. 